\title{
Mbailundu Remembered: \\ Colonial Traces in Post-Civil War Angola
}

\author{
SHANA MELNYSYN \\ University of California Humanities Research Institute \\ https://orcid.org/0000-0001-8880-6102
}

\begin{abstract}
This article traces connections between structures, identities and forms of collective belonging that impacted social relations in Angola from roughly the 1880s to 2013. In the absence of a coherent, centralised state structure, both during Portuguese colonialism and after independence in 1975, communities coalesced around regional and ethnic identities that had begun hardening under colonial rule. These structures of conflict and inequality animated the Angolan civil war (1975-2002). Through the lens of oral histories and collective memories of the early twentieth century, as well as archival records, I show how Angola's exclusionary identity politics were forged during colonial times and have persisted into the $21^{\text {st }}$ century. Focusing on the Umbundu speaking kingdom of Mbailundu, in Angola's central highlands, this article suggests that colonial structures of belonging and exclusion continue to affect political life in $21^{\text {st }}$ century Angola by maintaining stark divisions between people of different regional, ethnic and religious backgrounds. A fractured picture of belonging and loyalty emerged out of settler colonial structures in Angola and continues to reverberate in the political intrigues that overshadow everyday life.
\end{abstract}

\section{Introduction}

This article traces connections between power structures and forms of collective belonging that impacted social and political relations in Angola from roughly the $1880 \mathrm{~s}$ to 2013. In the absence of a coherent, centralised state structure during Portuguese colonialism, after independence in 1975 and throughout the civil war until 2002, communities coalesced around regional and ethnic identities that had begun hardening under colonial rule. Through the lens of oral histories and collective memories of the early twentieth century, as well as archival records, I show how Angola's exclusionary identity politics were forged during colonial times and have persisted into the $21^{\text {st }}$ century. As I have documented more extensively elsewhere, the scattered and uneven presence of Portuguese authorities throughout Angola during the colonial period resulted in a sociopolitical landscape in which power and authority were chaotically distributed and violently claimed by a variety of actors whose relation to the 
state was anything but straightforward. ${ }^{1}$ Claiming belonging in a group was a matter of life and death under colonial structures that valued assimilation, and questions of belonging continue to hold extremely high stakes in the $21^{\text {st }}$ century.

A fractured picture of loyalties and forms of belonging emerged out of settler colonial structures in Angola. These structures of conflict and inequality animated the Angolan civil war (1975-2002) and they continue to inform political conflicts post-civil war Angola. The MPLA (Movimento Popular da Libertação de Angola) emerged triumphant at the end of the war and continues to hold power in Angola today. President José Eduardo dos Santos was the head of the party and the president of Angola from 1977-2017. The MPLA adopted socialist ideals and received crucial financial support from the Soviet Union and direct military support from Cuba, receiving thousands of soldiers from the Caribbean nation. The party drew its support mostly from coastal urban Kimbundu and Portuguese speakers, with a considerable contingent of mestiço (mixed race) and white supporters. On the other hand, UNITA (União Nacional para a Independência Total de Angola) emerged as the primary opposition movement after other competing groups dissolved by the early 1980s. UNITA became associated with Ovimbundu² people from the central highlands and the party's leader, Jonas Savimbi, was known to give fiery speeches in both Portuguese and Umbundu. The civil war continued between the armed forces of the MPLA, which enjoyed some international recognition, and UNITA, which was receiving support from the United States and South Africa.

A brief anecdote from fieldwork illustrates how these histories continued to reverberate even in 2013. A woman in her late 40s, with whom I had many conversations, related the story of a prominent Ovimbundu businessman and politician, Valentim Amões. After the end of the war in 2002, Amões had risen in the ranks of the ruling MPLA, eventually becoming a member of the ruling party's central committee in Luanda. He was known for starting many successful businesses in the central highlands, and his generosity was legendary. Amões died in a plane crash near Bailundo in 2008. As I learned, many people do not believe the crash was an accident. ${ }^{3}$ An Ovimbundu could never rise as high as Amões did and make it out alive, I was told. If you are from the central highlands, you will never be trusted in Luanda. Naively, before I began this project, I thought an oral history project might be considered rather innocuous. But as I found in 2013, even discussions of events that sometimes felt like ancient history (1902) were thoroughly politicised. Histories were recounted and narrated in ways that aligned with rival party politics, reflecting a deep ideological fracture that impacts nearly every aspect of social and economic life. After six months poking around Huambo and Bailundo asking questions, I developed an acute awareness that MPLA officials were paying attention to my movements

1 S. Melnysyn, Vagabond States: Boundaries and Belonging in Portuguese Angola, c. 1880-1910. (PhD Dissertation, University of Michigan. 2017.

Collective ethnonym for the Umbundu speaking peoples of Angola's central highlands.

Informal conversation between author and female informant in her mid-40s. Huambo, Angola, June 2013. See also: http://www. angonoticias.com/Artigos/item/16917/empresario-valentim-amoes-morre-em-acidente-de-aviacao 
and contacts. Even a historical project that could seem politically neutral was highly politicised at every turn.

Focusing on histories of the Umbundu speaking kingdom of Mbailundu, in Angola's central highlands, this article suggests that structures of belonging and exclusion that were cemented during Portuguese colonial rule continue to affect political life in $21^{\text {st }}$ century Angola by maintaining stark divisions between people of different regional, ethnic and religious backgrounds. UNITA's tacit self-definition as representative of the Ovimbundu people has deeper roots in territorial struggles dating back to the late $19^{\text {th }}$ century. Specifically, I analyse highly politicised historical memories of the 1902 Mbailundu Revolt. During this uprising, recorded in archives as one of the most destabilising challenges to colonial rule, warriors from the Mbailundu kingdom and their allies sacked trading houses. During these raids, the warriors kidnapped and killed traders, the majority of whom were black or mestiço Angolans with ties to symbols of Portuguese power - they wore western clothing, practised Catholicism, produced rum, or were literate. The targeting of these middle figures, who sat uncomfortably at the interstices of colonial power and local forms of authority, reverberated during the Angolan civil war and beyond - as some of UNITA's rhetoric classified outsiders, namely Angolans who were not Ovimbundu but especially those from the coast, as enemies. In contrast, this political rhetoric cast Ovimbundu as the true, African Angolans, recalling the violent rejection of middle figures that had come before.

Given this historical backdrop, this article asks: How do contemporary, competing nationalist narratives in Angola involve a reimagination of key historical narratives? How might historical retellings of the Mbailundu Revolt by different political actors illuminate the salience of colonial traces in fashioning contemporary political identities? What happens to Cold War structures and logics after the geo-political forces behind them are dismantled? How do old divisions become transmuted into different forms of suspicion and division?

\section{A brief history of Mbailundu and colonial authority}

Well into the early $20^{\text {th }}$ century, Portuguese authorities and their henchmen struggled to contain the power of a polity in the central highlands known as Mbailundu. The kingdom had dominated trade in the central highlands since the Portuguese defeat of the rival kingdom of Viye in 1890. Mbailundu officially became a vassal of the Portuguese crown in the 1770s, but relations between the two polities were explosively unstable and revolts were frequent until at least the $1830 \mathrm{~s} .{ }^{4}$ By the turn of the $20^{\text {th }}$ century, when Mbailundu rose up against encroaching Portuguese settlement, the kingdom was arguably more 'state-like' than the colonial government that still struggled to find its footing. Traders, like those who lost their lives during the 1902 revolt,

4 Sociedade de Geografía de Lisboa (SGL), 'Notícia do Sertão do Balundo, por Candido de Almeida Sandoval, 1837', Annaes do Conselho Ultramarino, Serié I, Fev. 1854-Dez. 1858, 519-21. 
attempted to impose their authority on local populations by affiliating themselves with the state's symbolic power. They were met with total rejection by those who envisioned a different political future for Mbailundu and the surrounding region.

Mbailundu continues to be a locus of traditional Ovimbundu identity and spirituality, and its significance is deeply intertwined with both UNITA and IECA (Igreja Evangêlica Congregacional de Angola), a Protestant church with roots in the legacy of North American Congregationalist missionaries from the ABCFM (American Board of Commissioners for Foreign Missions). ${ }^{5}$ In 2013, when I conducted fieldwork, the language of 'invasion' and 'conquest' was still circulating in the central highlands, particularly among people with ties to UNITA. The forms of suspicion, competition and division in $21^{\text {st }}$ century Angola run along lines that can simultaneously be branded as ethnic, regional and partisan. Animosity is often articulated in terms that mirror colonial ones. At least from the perspective of many people in the area of Huambo and Bailundo, their homeland has been continuously invaded for decades. They see the MPLA's exclusive grip on political and economic power as an injustice, as outsiders encroaching on what is their legacy and their pride.

But while UNITA supporters understood the persecution of Ovimbundu people by the MPLA government and its Cuban allies during the civil war as invasive and colonial, UNITA itself has also framed itself and its political project through a language of ethnic chauvinism, rejecting coastal (read: 'Creole') Angolans as 'foreigners.' The party even claims that Angola's longstanding president (in office from 1979-2017), José Eduardo dos Santos, was born in São Tomé and have demanded he produce his birth certificate. ${ }^{6}$ A 1999 statement from UNITA claims that the party represents 'the excluded and the marginalised in their own country. The authors refer to themselves, notably, as 'African Angolans', and pledge to destroy 'the oligarchic regime of foreigners led by Jose Eduardo dos Santos.7 The struggle is framed in terms of insiders vs. outsiders, foreigners (creoles, mestiços) vs 'African' Angolans.

Many who supported the governing MPLA, however, considered UNITA's leader Jonas Savimbi a war criminal who needlessly hindered Angola's transition to peace in the service of his own grandiose obsession with winning the war. Considerable animosity and distrust were expressed on both sides. Many people from Luanda referred to Ovimbundu as 'traitors' and 'savages'. There was a sense from people on both sides of this divide that those from the other group could never be fully trusted. Although I was conducting this research during a post-war economic boom, a moment of peace and (unevenly distributed) prosperity, it was clear that a war-like attitude persisted, an anxiety that bubbled underneath the surface at all times. When I met people in Luanda and told them about my research, some asked me what I had been doing in 
'the south', and even expressed suspicions that I must be a UNITA supporter by virtue of my interest in that part of the country.

\section{Portuguese colonialism}

As effective occupation became necessary for European nations to maintain their African territories after the Berlin Conference of 1885, Portuguese authorities scrambled to establish control over the Angolan population. In the late $19^{\text {th }}$ century, colonial officials began to enforce the establishment of clear boundaries of ethnicity, harnessing emergent ideas based in the pseudoscience of race, in order to force people into categories that were 'legible' to state bureaucratic structures. The very conditions that the slave trade and colonial occupation had fostered - hybridity, chaos, migration, rapidly changing social structures, mass violence - became more problematic for Portugal as the imperative to settle Angola grew. Besides the colonial state, local polities also responded to the imperative to draw boundaries by attempting to consolidate and centralise their own power, sometimes by joining forces with colonial authorities in order to vanquish rival kingdoms.

According to both oral histories and archival evidence, Mbailundu emerged as a political formation around 1700 - during the height of the transatlantic slave trade and more than two centuries after Portuguese explorers landed near the mouth of the Congo River in $1483 .^{8}$ According to oral tradition, the kingdom's first ruler was a rifle-toting hunter who hailed from what is now Kwanza Sul, a province to the northwest of modern-day Bailundo. Today that region is Kimbundu speaking, and not considered part of the Umbundu speaking (Ovimbundu) region of Angola.

Local people found their own ways to create meaning and order during chaotic times, and the new religious paradigm introduced by North American Protestant missionaries during the last two decades of the $19^{\text {th }}$ century offered a space to do so. As Heywood has shown, Umbundu speakers at the end of the nineteenth century were more likely to identify with the kingdom to which they belonged than with any broader ethnolinguistic collectivity. ${ }^{9}$ The missionaries developed a written inventory of the language, translated the Bible into Umbundu, and aggressively evangelised central highlands communities with the help of Ovimbundu converts, thereby introducing a common thread of social belonging and laying the groundwork for ethnic solidarity. The consolidation of an ethnic 'Ovimbundu' identity was encouraged by the activities of Protestant missionaries. ${ }^{10}$ In turn, this religious and institutional foundation created opportunities for organisation and mobilisation throughout the $20^{\text {th }}$ century. ${ }^{11}$ Justin Pearce argues that many UNITA followers felt their movement

8 M. L. M. Sungo, 'O Reino de Mbailundu: Identidade e Soberania Politica no Contexto do Estado Nacional Angolano Atual' (MA thesis, Universidade Federal de Santa Catarina, 2015), 82.

9 L. Heywood, Contested Power in Angola, 1840s to the Present (Rochester, NY: University of Rochester Press, 2000$), 2$.

10 L. Heywood, 'Towards an Understanding of Modern Political Ideology in Africa: The Case of the Ovimbundu of Angola', The Journal of Modern African Studies, 36,1, 1998, 139-167.

11 For more on the complicated legacy of the Congregationalist missionaries in Angola, see K. Burlingham, "In the Image of God": A Global History of the North American Congregational Mission Movement in Angola, 1879-1975' (PhD Dissertation, Rutgers University, 2011). 
was 'defending an authentic, black African and Christian Angola that was under assault from an atheist Creole-dominated state in Luanda that was also the tool of Soviet imperialism. ${ }^{12}$ Martins has shown how decades of being negatively associated with UNITA, Ovimbundu people's sense of their own marginalisation within Angola has been reinforced. ${ }^{13}$

\section{The Mbailundu Revolt}

In many ways, the 1902 Mbailundu Revolt was an assertion of Ovimbundu sovereignty against not only colonial officials hailing directly from Portugal, but also their mestiço sons and daughters, black traders and soldiers, and even the servants and slaves of anyone considered 'foreign' (as in not Ovimbundu). Starting in April 1902, Ovimbundu nobility rejected the authority of the Portuguese captain major at the fort on their lands and led tens of thousands of subjects of the Mbailundu kingdom and its allies in attacking mostly white, mestiço, and Luso-African traders and colonial officials. These gentio - 'gentiles' or 'heathens' as the Portuguese referred to the masses of 'unassimilated' - continued a long tradition of resistance by Umbundu speakers to the growing interference of 'strangers' ${ }^{14}$ in their commercial and political affairs. By staging this uprising, the rebels paralysed commerce and communication between the coast and the central highlands for six months. Mbailundu people and their allies sacked and burned commercial houses, chained captive traders together, and forced them to march and carry heavy loads like caravan porters.

Most sources on the Mbailundu Revolt have used missionary letters and published Portuguese texts to reconstruct the events. Each has contributed to a general understanding of the causes of the uprising and the intentions of its organisers. But few have outlined the direct links between events like earlier acts of aggression against traders, and the complicated alliances and antagonisms that facilitated these dynamics. My work has traced the inconsistent interventions by the Portuguese military and the atrocious treatment by traders and soldiers that communities in the central highlands suffered leading up to 1902. The accumulation of moral outrage over such incidents provided the energy behind this extraordinary revolt, though uprisings were nothing new in Angola. Gentio had engaged in sporadic resistance to Portuguese rule throughout four centuries of occupation. But the 1902 revolt represented an unprecedented threat to colonial power. American Protestant missionary Wesley Stover noted, 'So general an uprising is an unheard of thing in this part of Africa. ${ }^{15}$

Historians Wheeler and Christensen, who published one of the few academic articles on the Mbailundu Revolt in 1973, took the title of their study from a report composed by the missionary Bertha Stover, who found it remarkable that the people

\footnotetext{
J. Pearce, Political Identity and Conflict in Central Angola, 1975-2002 (Cambridge: Cambridge University Press, 2015 ), 14.

V. Martins, 'Ovimbundu Identity Attributions in Post-War Angola', Journal of Southern African Studies, 41, 4, 2015, 853-867.

G. Simmel, 'The Sociological Significance of the "Stranger"' in R. E. Park and E. W. Burgess (eds), Introduction to the Science of Sociology (Chicago: University of Chicago Press, 1921), 322-327.

15 American Board of Commissioners (ABC) 15, 1, Bertha Stover Report, July 1902, 10.
} 
were able 'to rise with one mind' against the Portuguese. ${ }^{16}$ But other scholars have claimed that a spirit of 'fierce individualism' among the Ovimbundu ultimately led to the revolt's failure. ${ }^{17}$ According to Linda Heywood, the uprising was 'a reassertion of sovereignty by the Ovimbundu nobility over their lands, which they saw the Portuguese as undermining, reinforced by the complaints of the lower classes against the demands of the Portuguese for their services as porters in areas where armed force had given them temporary control. ${ }^{18}$ Renee Pélissier argues that joint exploitation by coastal merchants and military forces under Captain Majors was the main grievance of those who joined the revolt. ${ }^{19} \mathrm{He}$ also claims that the lack of understanding between the Governor General in Luanda, Cabral Moncada, and the Governor of Benguela, Joaquim Teixeira Moutinho, was 'notorious'. This undoubtedly contributed to the delayed response on the part of colonial authorities during the early days of the revolt. ${ }^{20}$

By focusing on the micro-level social interactions surrounding the revolt, my analysis emphasises the important social processes of boundary making that were underway, pushed by Mbailundu nobles who led the revolt as much as by colonial agents. Portuguese authorities had their reasons for drawing lines between groups as they tried to push Angolans into colonial submission. Mixed and intermediary individuals, whose loyalties were always in question, would have no place in this new colonial society. Portuguese officials expressed considerable anxiety about the fact that many of the representatives of colonial power in the interior were mestiços who straddled colonial and African worlds. For metropolitan Portuguese agents trying to enforce a different hierarchy with themselves at the top, these middle figures presented a major obstacle. Mariana Candido points out the irony that these intermediary agents 'were a menace to colonialism, yet they represented the colonial state in the region. ${ }^{21}$

Wheeler and Christensen suggest that 'Africans ultimately killed more mestiços and so-called 'civilised blacks' ... than whites during the course of the war'. What much of the violence of the Mbailundu Revolt amounted to, besides an attack on the Portuguese state, was a settling of old scores against westernised blacks. ${ }^{22}$ Even the slaves and domestic servants of such traders wound up imprisoned in rebel war camps. Missionary Bertha Stover wrote, 'A half caste [sic] whom we know and whose wife has been to the station for medical help had his head cut off, heart cut out and they were put into a basket and the wife was made to carry them to camp'. According to Stover this mestiço trader 'was an especially cruel man. ${ }^{23}$ Portuguese Lieutenant

16 D. Wheeler and D. Christensen, 'To Rise with One Mind: The Bailundu War of 1902' in F. Heimer (ed), Social Change in Angola (München: Weltform Verlag, 1973), 70.

17 F. Soremekun, 'The Bailundu Revolt, 1902', African Social Research, 16, 1973, 463.

18 L. Heywood, Production, Trade and Power in the Political Economy of Central Angola, 1850-1930 (PhD Dissertation, Columbia University, 1984), 321.

19 R. Pélissier, História das Campanhas de Angola: resistência e revoltas (1845-1941) Vol. II, (Lisbon: Editorial Estampa, 1986$)$, 84.

20 T. Moutinho, Em Legitima Defesa: Resposta ao Livro (1a Edição) do Exmo. Senhor Conselheiro Cabral Moncada, Intitulado: A Campanha do Bailundo (Lisboa: Livraria Editoria Viuva Tavares Cardoso, 1904).

21 M. Candido, An African Slaving Port and the Atlantic World: Benguela and its Hinterland (New York: Cambridge University Press, 2013), 316-17.

22 Wheeler and Christensen, 73.

23 ABC 15, 1, Bertha Stover Report, July 1902, 2. 
Pais Brandão briefly recounted the story of 'Paschoal ambaquista', whose house was burned by rebels before he was hunted down, killed and 'eaten over fire. ${ }^{24}$ Black Angolans like ambaquistas, who adopted many European lifeways and lived outside of the social structures of polities like Mbailundu, were at least as hated as whites. Recent work on the eighteenth century in Angola shows that this enmity and competition between such 'in-between' figures and groups of gentio was longstanding. ${ }^{25}$ These legacies of colonial power are still operative in $21^{\text {st }}$ century Angola.

\section{Bailundo's symbolic weight}

During the 1990s, as Angola's civil war forged on in cycles, people were targeted in the capital city of Luanda for being bailundos - a general term for people speaking Umbundu and presumed to be from anywhere in the central highlands, often used in a derogatory way. ${ }^{26}$ In October 1992, after UNITA disputed the results of the national election and ended the associated ceasefire, MPLA soldiers handed out weapons to its civilian supporters in the peripheral neighborhoods of Luanda. A wave of mass killings followed with at least 2000 Umbundu speakers executed by a mob 'for being UNITA' ${ }^{27}$ UNITA's own estimates of the number killed on that day reach a staggering $30,000 .{ }^{28}$ This particular moment of violence in a long civil war depended upon the conflation of ethnicity or regional origin with political loyalty. Karl Maier, a journalist who covered Angola extensively in the 1990s, suggests that memories of the 1902 Mbailundu Revolt continued to contribute to conflict between coastal urban mestiços and Ovimbundu nearly a century later, inflecting the civil war. ${ }^{29}$

UNITA's headquarters were located in the town of Bailundo from 1994-1999, and some of the most intense conflict happened during those years in Bailundo and in nearby Huambo. ${ }^{30}$ The scars of this legacy were everywhere in 2013. Bullet holes riddled the facades of mid-century buildings. A few buildings even had collapsed roofs or holes blown out of the sides from bombing, yet people still made homes within them. Even Savimbi's one-time home, a large, once majestic house near the Huambo airport, was still standing despite its roof having been folded in two by a mortar in the 1990s when the armed conflict plagued Huambo. A grand, hulking structure with a spiral staircase at its core, the house was referred to by locals as the 'casa branca' (white house), both a literal description and probably a sardonic nod to Washington's support for UNITA during the 1980s and 90s. In 2013, the damaged structure still sat undisturbed, inhabited by a young family of dreadlocked Rastas, right next door to Huambo's UNITA headquarters.

\footnotetext{
Arquivo Histórico Militar (AHM), 2/2/7/21, Relatório das Operações do Bailundo, 85.

5 Candido, An African Slaving Port. See also: R. Ferreira, Cross-Cultural Exchange in the Atlantic World: Angola and Brazil during the Era of the Slave Trade (New York: Cambridge University Press, 2012).

6 K. Maier, Angola: Promises and Lies (London: Serif Books, 1996), 97.

Maier, 124.

UNITA Standing Committee Statement, 1999.

Maier, 191.

0 F. Florêncio, 'Un Reino, Dos Reyes: Diferentes Legitimidades en Bailundo (Angola)', Revista CIDOB d'Afers Internacionals, 87, 2009, 167-189.
} 


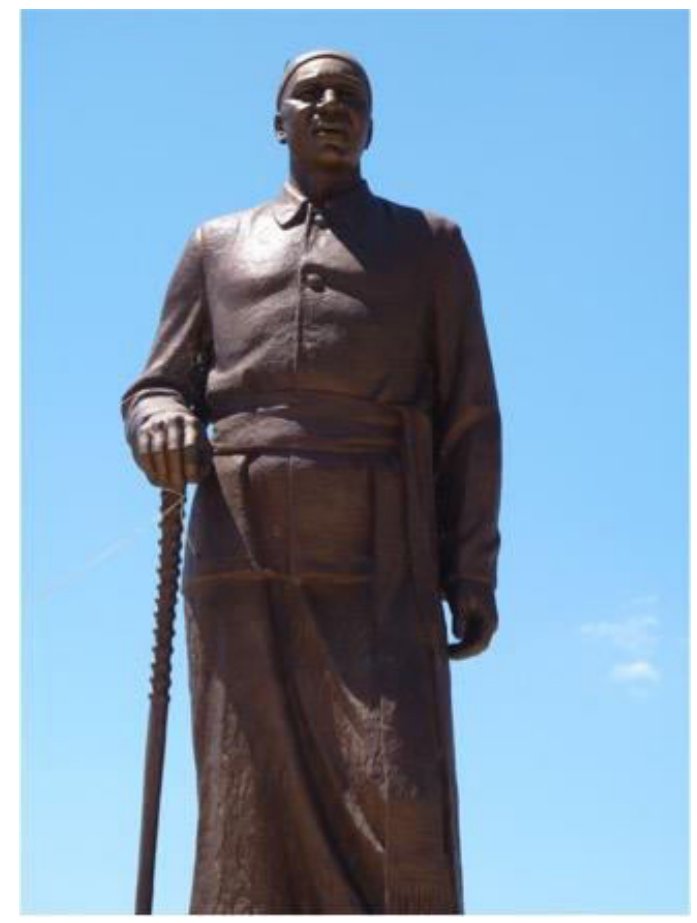

Figure 1: Statue of Ekuikui II, Bailundo (2013, photo by author)

Jonas Savimbi's own personal history was deeply entangled with Mbailundu, and with the attendant structures of historical memory and identity. His grandfather, Sakaita Savimbi, fought in the 1902 Mbailundu Revolt. ${ }^{31}$ His father, Loth, was a Protestant pastor educated by the ABCFM missionaries, and worked on the construction of the Benguela Railroad during the height of Portuguese settler colonialism in the mid- $20^{\text {th }}$ century. ${ }^{32}$ The family biography of the figure most closely associated with UNITA and its political project is entangled with the history of Mbailundu.

In the traffic circle that marks the tiny center of the town of Bailundo, a huge metal statue of the late $19^{\text {th }}$-century Mbailundu king Ekuikui II towers over passing cars and pedestrians. Erected in 2010, the statue was dedicated in a ceremony led by the Minister of Culture, part of the festivities around Angola's $35^{\text {th }}$ anniversary of independence from Portugal, 'in recognition of [Ekuikui's] deeds and kingdom during the struggle against the Portuguese colonial invasion. ${ }^{33}$ The statue itself indexes a careful management of the symbols of Mbailundu's history by the ruling MPLA government, a casting into metal of the state-sanctioned narrative of 'anti-colonial resistance' embodied by the memories of this powerful ruler. The centralised state-like 
structure of Mbailundu, along with its history of resistance to Portuguese control, make it an attractive addition to the MPLA's linear narrative of triumph over colonial dominance.

In truth, during Ekuikui II's reign over Mbailundu (1876-1893), the number of white missionaries, settlers and administrators in the area increased at an unprecedented rate. He allowed Portuguese traders to settle and establish shops near Mbailundu. Ekuikui II also wrote to the central colonial government, requesting that a Portuguese Captain be stationed permanently at Bailundo. Ekuikui II's wish was not granted until after his death, when a fort at Bailundo was constructed in 1895. The Mbailundu ombala (seat of royal power, court), perched at that time atop the rocky outcropping known locally as Halavala, towered above the colonial fort. ${ }^{34}$ Lieutenant Pais Brandão, whose troops killed rebel leader Mutu-ya-Kavela and put down the Mbailundu Revolt, wrote that the fort was in the worst possible defensive conditions ${ }^{35}$ An official passing through in 1901 described the fort as a collection of 'small buildings', and remarked, 'The situation of this fort is terrible, perfectly dominated by the neighboring embala', ${ }^{36}$ Another Portuguese officer described it as a 'fort that looks more like a hut [cubata] ${ }^{37}$ Of the neighboring kingdom of Wambu (Huambo), less powerful but even more resistant and elusive than Mbailundu, a 1902 Lisbon newspaper gave the following description: 'The region is mountainous and the ruggedness of the terrain contributes to the difficulty of a definitive occupation. It is, without a doubt, the cause of the arrogance of its natives. ${ }^{38}$ Even the physical landscape and the built environment of the highlands reflected the imbalance of power that continued to impede Portuguese control.

If the power imbalance favored Mbailundu during the years while Ekuikui II reigned, the ruler still sought an ally in Portugal to help him with his sustained wars with neighboring rival Ovimbundu kingdoms. This factionalism amongst the highland kingdoms ultimately helped facilitate the conquest of the central highlands by Portuguese troops, as olosomas (kings or paramount chiefs, which the Portuguese referred to as 'sobas', a term that is still used in Angola today) plotted against one another in the quest for dominance. ${ }^{39}$ But the significance of the leader is streamlined within oral history narratives told by supporters of both UNITA and the MPLA. For the MPLA, figures like Ekuikui II fit neatly into the state-sanctioned narrative of disciplined, kingly masculine strength, which overcomes colonial invasion through cunning and moral superiority. As Jessica Krug has shown in her study of Kisama, it is exceedingly difficult to access histories of peoples whose social organisation does not fit into the structures recognised by states. ${ }^{40}$ Histories of Mbailundu, on the other

\footnotetext{
'Portugal em Africa', Revista Scientifica, Publicação Mensal, 9, Junho 1902, 362. AHM 2/2/7/21, 35.

A. Malheiro (1901), quoted in R. Delgado, Ao Sul da Cuanza: Ocupação e Aproveitamento do Antigo Reino de Benguela, Vol. I (Lisboa: Imprensa Beleza, 1941).

7 AHM 2/2/7/3, 8 May 1901. Joaquim Luna de Carvalho to Governor of Benguela.

38 Biblioteca Nacional de Portugal (BNP), Lisboa, F.5701 (microfilm), Diário de Notícias, 8 Julho 1902, no. 13:147, ano 38.

39 H. de Paiva Couceiro, Relatório de Viagem entre Bailundo e as Terras do Mucusso (Lisboa: Imprensa Nacional, 1892 ), 8.

40 J. Krug, Fugitive Modernities: Kisama and the Politics of Freedom (Durham and London: Duke University Press, 2018).
} 
hand, are desirable targets for projecting political ideals and fashioning nationalist narratives and alternative histories that seek legitimacy by invoking state-like structures.

The fact that Ekuikui II provided the assistance to the Portuguese to overthrow the neighboring ruler of Viye (another Ovimbundu kingdom), thereby strategically opening the way for Mbailundu to rise to prominence, is mentioned far less frequently than other parts of his history. This fact normally was not emphasised to me by those I interviewed, regardless of their political loyalties. Ekuikui II's memory is revered by those in the UNITA camp where he is remembered for the stability and prosperity associated with the period of his reign, as well as the fact that he ushered in the most significant period of missionary influence in the area. It was Ekuikui II, after all, who first allowed North American Protestant missionaries to settle near Mbailundu in $1881 .{ }^{41}$

As a vassal of the Portuguese King, Ekuikui II wrote many letters to colonial authorities in Luanda, which provide a fascinating window into this powerful leader's relationship with the colonial state. In 1884, Ekuikui wrote to the Governor of Benguela asking him to send 'a representative of the nation [Portugal] with whom I can communicate in order to deliberate about what is most convenient for this country [Mbailundu], and also at least a good priest to teach my children to read and write. ${ }^{42}$ In 1886, Ekuikui requested permission from the chief administrator of Catumbela (a coastal port city) to take military action against some groups in Quibula and Quissama who were attacking caravans. He told the official he wanted to 'civilise' these groups. ${ }^{43}$ This letter deliberately positions Mbailundu in stark contrast to places like Quissama (elsewhere spelled Kisama), which evaded Portuguese conquest and eschewed rigid hierarchies. ${ }^{44}$ In his letters to Luanda, Ekuikui II also asked for envelopes, pens and ink, and repeated his request for a priest to come to Mbailundu and baptise his people and open a school. As Maria da Conceição Neto has shown, leaders like Ekuikui II saw the benefits of becoming vassals of the Portuguese crown and considered themselves independent rulers while their vassalage made them subordinate to colonial interests. But this subordination was always tied to contingent and ever-shifting circumstances. ${ }^{45}$

Ekuikui II's offer to help Portuguese authorities 'civilise' other groups is a fascinating glimpse in the ways in which power operated within colonial rubrics. Even in the $21^{\text {st }}$ century, there is a sense among some Ovimbundu that their people were entrusted with the project of 'civilising' the rest of the country by sharing their superior knowledge. I interviewed a Bailundo resident who was a UNITA supporter and

41 M. da Conceição Neto, In and Out of Town: A Social History of Huambo (Angola), 1902-1961 (PhD Dissertation, SOAS, 2012), 70 .

42 AHA, Luanda. 16/5/1884. Dom Equiqui Sobba do Bailundo ao Governador de Benguela, 12 March 1884.

43 AHA, Luanda. 16/5/1884. Dom Equiqui Sobba do Bailundo ao Chefe d'Concelho de Catumbela, 18 September 1886.

44 See Krug, 2018.

45 M. da Conceição Neto, 'Hóspedes Incómodos: Portugueses e Americanos no Bailundo no Último Quartel do Século XIX', Actas do Seminário Encontro de Povos e Culturas em Angola - Luanda, 3 a 6 de Abril de 1995 (Luanda: Commissão Nacional para as Comemorações dos Descobrimentos Portugueses, 1995), 378. 
a member of the Protestant church. He was born in 1951 and painted the Bailundo of his youth as a virtual paradise. He delivered a hyperbolic paean to the greatness of his people, recounted on a sunny day in May 2013 in his mother's home in Bailundo. According to his narrative, there had been no theft, no traffic accidents and even no mosquitoes there until around 1979. In his view, civilisation, Christianity and education had spread out to the rest of Angola from Bailundo. According to his telling, the Portuguese colonisers had wanted to exterminate the people of Mbailundu because of their education and abilities. But the missionaries defended Mbailundu:

The missionaries had a vision of decolonisation. That's just to say that everyone who made revolution against the colonisers came out of Mbailundu and were Protestants. When the Portuguese said 'you have to work for us, blacks are slaves', the missionaries said otherwise. ${ }^{46}$

What's interesting about these statements is the claim that everyone who fought against the Portuguese was Protestant and Mbailundu. They foreclose the possibility of valid anticolonial resistance being attributed to anyone other than the speaker's own groups. Furthermore, he follows this claim by directly tying it to the missionaries' condemnation of slavery and their protection of Mbailundu people from enslavement and forced labor.

This was not the only instance where someone related a story of ABCFM missionaries protecting people from colonial exploitation. João Elenge, a man in his 80s who is a member of UNITA and the Congregational Church, told me an emotional story in 2013. When he was a child in the 1940s, he came home from school one day to find his mother missing. The neighbors told Elenge that his mother had been taken to work on the construction of a road, a common form of forced labor enforced throughout Angola during the twentieth century. Elenge enlisted the help of a local resident Canadian missionary, and the two went directly to the work site. The missionary confronted the Portuguese supervisor and brought Elenge's mother home.

Elenge recounted the story about his mother with great drama and emotion, drawing to a conclusion with tears brimming in his eyes: 'This was the first pact that the Angolan had with America. A sacred pact ... that we needed very much' Elenge's implication here was that this 'pact' between the missionaries and the people of Bailundo was a prelude to the rest of the $20^{\text {th }}$ century - the advocacy the Protestant missionaries provided by smuggling information about forced labor out of Angola and reporting it to the United Nations, and the military and financial support that UNITA would later receive from the United States in the 1980s when Cold War interests aimed at impeding the ability of the Cuban and Russian-backed MPLA to sustain power. Thanks to this shared history, Elenge said, 'We can receive any American visitor who comes here as a brother, thank God'47

46 Author interview with Afendo Epomba, Bailundo, 16 April 2013.

47 Author interview with João Elenge, Bailundo, 3 May 2013. 
This story was told to me, an American, at the UNITA party headquarters in Bailundo, as I sat in a circle of elderly men beneath a huge photograph of Jonas Savimbi. Interestingly, despite the discourse of invasion that is circulated amongst UNITA supporters, the long North American missionary history in this region is almost unanimously remembered by contemporary highland Protestants with great pride and reverence. The missionaries' work spreading literacy and institutionalising the use of the Umbundu language set the stage for a peculiarly Ovimbundu Protestant identity to develop, leading to a form of nationalism that was invested in particular markers of modernity. ${ }^{48}$ Many Angolans from the highlands told me that Ovimbundu Protestants were commonly referred to as 'americanos' during the $20^{\text {th }}$ century because of their association with the missionaries.

The boundaries that the colonial state began to enforce after the Mbailundu Revolt in 1902 had hardened even further by the 1960s. The proliferation of social categories that had circulated in the late nineteenth and early twentieth century had succumbed to the pressure of the Portuguese state within the decades following the revolt. David Birmingham has shown how an increasingly aggressive strain of settler colonialism gradually replaced an older class-based system of social classification with a stricter division between 'citizens' and 'natives', culminating with the introduction of the Native Statute in $1926 .{ }^{49}$ Evidence suggests that assimilados (those enjoying increased rights and privileges by virtue of proving their status as 'assimilated' or 'civilised' Africans) were specifically feared and targeted by Portuguese police. According to ABCFM missionary Gilchrist, who wrote to the United Nations to report on colonial atrocities in Angola, some people 'were shot for simply being found with pencils or pens - these indicated that their owner could write and hence was potentially dangerous. ${ }^{50}$ Ambivalent feelings about black Africans adopting European dress and customs, which had been common amongst Portuguese commentators during the late $19^{\text {th }}$ century, developed into full-fledged hatred as settler colonialism took hold. Pointing to the importance of clothing in the performance of identities, some assimilados were told by white settlers, 'We'll take the pants off all you bastards. ${ }^{.51}$ It is interesting, then, that a sense of Ovimbundu political identity that persists today combines an assertion of 'true' undiluted African-ness with a sense of pride in having served in a 'civilising' role in relation to the rest of the country.

\section{Conclusion}

I snapped the above photograph of Ekuikui II's statue on the day when I interviewed the current Mbailundu king, Ekuikui V. I was escorted by a government official from the Ministry of Culture, João Afonso. When we arrived at Ekuikui's home, after paying the requisite tribute consisting of food, soft drinks and alcohol, Afonso and

\footnotetext{
Pearce, 25.

D. Birmingham, A Short History of Modern Angola (London: C. Hurst \& Co., 2015), 64.

I. Gilchrist, 'Witness to Terror', Africa Today 10, 4, 1963, 4-7.

Ibid.
} 
Ekuikui V spoke about a new gas station that had recently been built in the town. Ekuikui inquired about getting the first delivery of gasoline from the state oil company Sonangol. Ekuikui didn't have much to tell me about the Mbailundu Revolt, beyond what had been published in an MPLA pamphlet in the 1990s, which I had already encountered in the national archives. Our day together ended at the traffic circle where we gazed up at the towering statue. As Ekuikui V shook my hand and we said our goodbyes, he handed me a framed photograph of himself smiling and shaking hands with President dos Santos. It felt like a fitting capstone to a day that had been carefully curated by the government.

Other interlocutors had strong negative feelings about Ekuikui $\mathrm{V}$ and his relationship with the president. One man in his 40s, who had fought in the civil war on the side of UNITA and had clearly suffered the effects of the war's trauma, told me colourful stories about the nature of the alliance between the MPLA and Mbailundu's current leadership. He believed that President dos Santos had travelled around the entire country looking for a place to practise his sorcery, and that he had found a sanctuary in Mbailundu with Ekuikui V. Some of his stories involved suspicions about the involvement of China, and even the KGB, in this dark magic he assumed to be taking place in the Mbailundu ombala. The current king's legitimacy is called into question by many who claim that he is not the true heir to the throne. When I tried to interview a man who supposedly had knowledge of this lineage dispute, I was turned away. The man had just lost his daughter and he told me very matter-of-factly that the family suspected she had been poisoned. I wasn't surprised, then, that he didn't feel like talking to a foreign stranger about an extremely contentious political matter.

On one side of the road between Huambo and Bailundo in 2013, in the middle of a dusty clearing that served as both football pitch and roadside marketplace, the MPLA flag fluttered. Directly facing it from across the street, flew the UNITA flag with its galo negro (black rooster). Division and boundaries crowded this tiny space with the material and psychic remnants of a violent history. Nearby, a rusted out armored vehicle fused with the landscape by the side of a creek, an ever-present reminder of war. The rift is tangible in a political banner hung outside a Luanda school in 2013, with a picture of President dos Santos and an ominous warning: 'If you don't support the President, you support a return to war.' The deep legacy of violence in Angola -beset by the rapacious transatlantic slave trade, the indignities of settler colonialism and the nihilistic violence of a Cold War-inflected civil war - continues to scar the landscape and muddy the political waters in $21^{\text {st }}$ century Angola. Though the violence of the civil war still dominates popular memory, colonial traces can still be found in the contours of the conflicts that rage on. As one Bailundo elder put it, 'the arms have quieted, but the war is still cold.'. ${ }^{52}$ 